\title{
ON THE DEVELOPMENT OF THE SOUTHERN PART OF LAKE PEIPSI IN THE HOLOCENE
}

\author{
Avo MIIDEL a, Tiit HANG a, Reet PIRRUS a, and Arvi LIIVA b
}

a Eesti Teaduste Akadeemia Geoloogia Instituut (Institute of Geology, Estonian Academy of Sciences), Estonia pst. 7, EE-0100 Tallinn, Eesti (Estonia)

b Eesti Teaduste Akadeemia Zooloogia ja Botaanika Instituut (Institute of Zoology and Botany, Estonian Academy of Sciences), Riia 181, EE-2400 Tartu, Eesti (Estonia)

Received 8 July 1994, accepted 27 September 1994

\begin{abstract}
According to the palynological and geological data obtained at the mouth of the Optjok River, SE Estonia, a shallow lake existed in the southern part of the depression of Lake Peipsi at the beginning of the Preboreal. By the end of the Preboreal, the depression partly turned into a fen due to the lowering of the water level. The water level was up to $10 \mathrm{~m}$ lower than at present. A slow rise in the water level started earlier in the south and in the low areas in the first half of the Boreal. The slow rise continued until the second half of the Subboreal and then the water-level rise accelerated. The water-level rise is still in progress. As a result, the southern shore of the lake was subject to paludification, which spread to the lower reaches of rivers as well. The water-level rise was most likely caused by a combined effect of climatic factors and tectonic movements. The deep downcutting of rivers must have taken place considerably earlier than hitherto assumed.
\end{abstract}

Key words: Holocene, water-level changes, Lake Peipsi, palynology, floodplain mire, Estonia.

\section{INTRODUCTION}

It is generally known that an extremely thick cover of fen peat occurs in the lower reaches of the rivers flowing into the southern part of Lake Peipsi. The formation of fen peat is usually explained by the changing lake level. Therefore, it was expected that an investigation of the mouth area of the Optjok River would give some new information on the development and water-level changes of Lake Peipsi in the Holocene.

The Optjok River, SE Estonia, begins from Lake Mõla (45 m a.s.1.) and falls into the southern part of Lake Peipsi (Fig. 1). The total fall of the 24-km-long river is $15 \mathrm{~m}$, which is unevenly divided along the longitudinal profile. The profile is concave in shape (Fig. 2). Two thirds of the total fall is related to the 10-km-long upper portion (gradient $0.8 \mathrm{~m} / \mathrm{km}$ ) and one third to the $14-\mathrm{km}$-long lower reaches of the river (Fig. 2). The stream gradient affects the relation of lateral and bottom erosion. This relation has been the major factor in the formation of morphologically different parts of the valley. In its upper reaches the Optjok River flows in a deep (up to $60 \mathrm{~m}$ ) and narrow steep-sloped valley. The width of the channel in this part is only $5-10 \mathrm{~m}$. In the lower reaches the Optjok Valley is $700-1000 \mathrm{~m}$ wide with a low swampy floodplain, continuously flooded every year. The width of the channel is about $20-30 \mathrm{~m}$. 


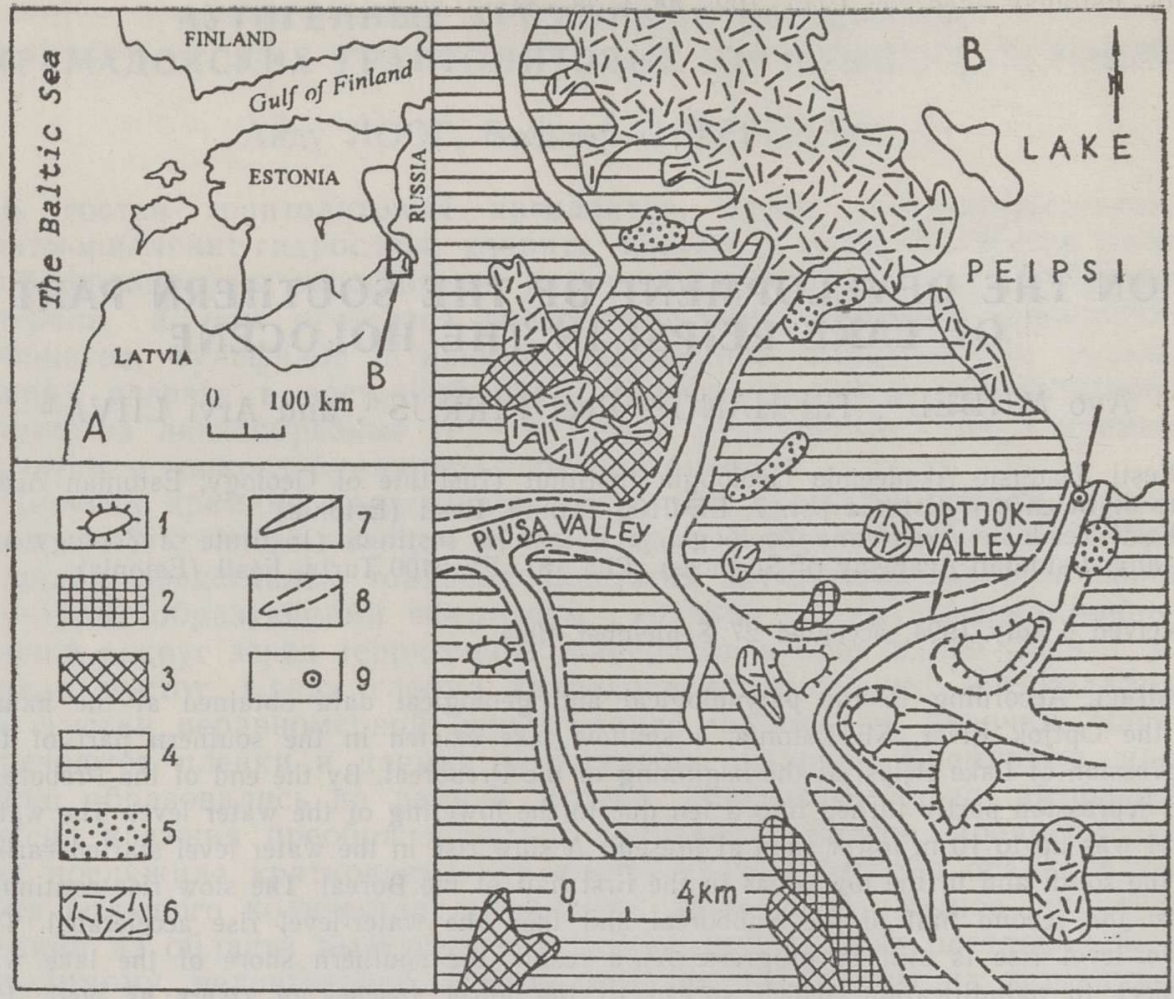

Fig. 1. Location map (A) and a geomorphological scheme of the area surrounding the investigated site $(\mathrm{B})$.

1 bedrock height; 2 endmoraine; 3 kame field; 4 glaciolacustrine plain; 5 dune field; 6 mire; 7 river valley; 8 bedrock valley; 9 investigated site.

The longitudinal profile, as well as the direction and morphology of the valley, is mostly controlled by the bedrock topography and lithology. The upper portion of the Optjok River together with Lake Mõla is situated in a deep pre-Quaternary valley cut into Devonian limestone (Fig. 1). This valley falls into a bigger W-E-oriented bedrock valley, which is eroded into Devonian sandstone. High bedrock remains are situated on the right bank of the valley (Fig. 1). The bedrock is covered with reddish-brown loamy till near Lake Mõla and, closer to Lake Peipsi, with fine-grained glaciolacustrine sand, which in places (near the coast of Lake Peipsi) has been blown into dunes (Fig. 1). The above-described Pre-Quaternary valleys are filled with up to 60 -m-thick glaciofluvial and glaciolacustrine deposits. Alluvial sediments in the Optjok Valley can be divided into fine-grained overbank facies with horizontal organic-rich laminae and channel facies containing coarse-grained sand and gravel. Only a few data about the thickness of alluvial deposits are available. Near Vašina-Gora the thickness of the alluvial sediments is about $5 \mathrm{~m}$ (Fig. 2). At the lower reaches of the river near Soha it is about $8 \mathrm{~m}$, including the 6 -m-thick peat cover. From the area near the mouth of the river no data about alluvial mineral sediments are available. In this part of the valley lacustrine silt is covered with peat $10 \mathrm{~m}$ in thickness (Fig. 2). 


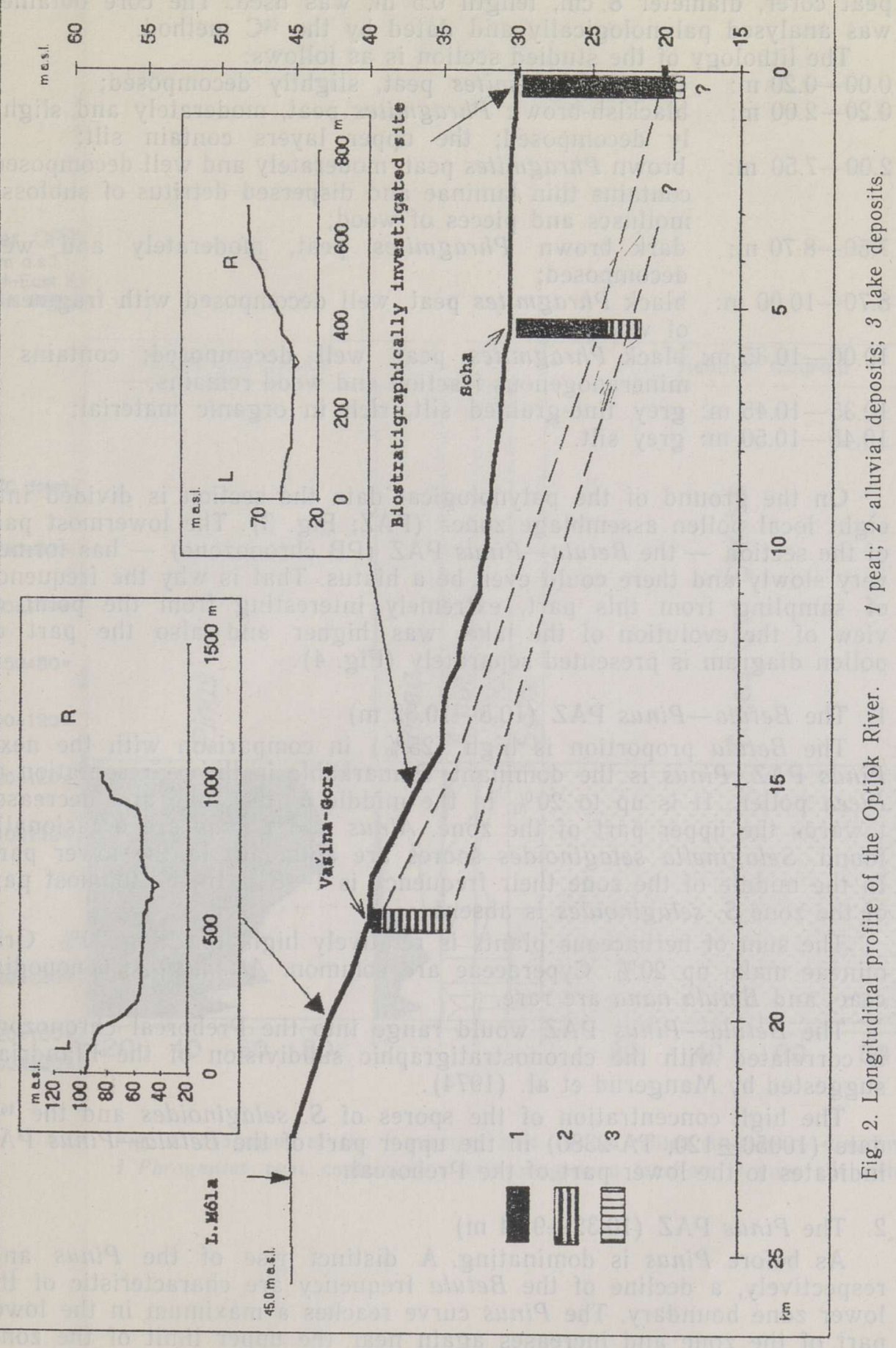




\section{THE OPTJOK SECTION AND ITS PALYNOLOGY}

The investigated site was situated on the left bank of the river, on the floodplain (30 $\mathrm{m}$ a.s.1.), about $100 \mathrm{~m}$ from Lake Peipsi. A Belarus peat corer, diameter $8 \mathrm{~cm}$, length $0.5 \mathrm{~m}$, was used. The core obtained was analysed palynologically and dated by the ${ }^{14} \mathrm{C}$ method.

The lithology of the studied section is as follows:

0.00-0.20 m: Carex-Phragmites peat, slightly decomposed;

$0.20-2.00 \mathrm{~m}$ : blackish-brown Phragmites peat, moderately and slightly decomposed; the upper layers contain silt;

2.00-7.50 m: brown Phragmites peat, moderately and well decomposed, contains thin laminae and dispersed detritus of subfossil molluscs and pieces of wood;

$7.50-8.70 \mathrm{~m}$ : dark brown Phragmites peat, moderately and well decomposed;

8.70-10.00 m: black Phragmites peat, well decomposed with fragments of wood;

10.00-10.35 m: black Phragmites peat, well decomposed; contains a mineranogenous fraction and wood remains;

$10.35-10.45 \mathrm{~m}$ : grey fine-grained silt, rich in organic material; $10.45-10.50 \mathrm{~m}$ : grey silt.

On the ground of the palynological data the section is divided into eight local pollen assemblage zones (PAZ; Fig. 3). The lowermost part of the section - the Betula-Pinus PAZ (PB chronozone) - has formed very slowly and there could even be a hiatus. That is why the frequency of sampling from this part, extremely interesting from the point of view of the evolution of the lake, was higher and also the part of pollen diagram is presented separately (Fig. 4).

\section{The Betula-Pinus PAZ (10.5-10.32 m)}

The Betula proportion is high $(25 \%)$ in comparison with the next, Pinus PAZ. Pinus is the dominant. Remarkable is the representation of Picea pollen. It is up to $20 \%$ in the middle of the zone and decreases towards the upper part of the zone. Alnus and Ulmus are occasionally found. Selaginella selaginoides spores are abundant in the lower part. In the middle of the zone their frequency is $1-8 \%$. In the topmost part of the zone $S$. selaginoides is absent.

The sum of herbaceous plants is relatively high, reaching $20 \%$. Gramineae make up 20\%. Cyperaceae are common. Artemisia, Chenopodiaceae, and Betula nana are rare.

The Betula-Pinus PAZ would range into the Preboreal chronozone if correlated with the chronostratigraphic subdivision of the Flandrian suggested by Mangerud et al. (1974).

The high concentration of the spores of $S$. selaginoides and the ${ }^{14} \mathrm{C}$ date $(10050 \pm 120, \mathrm{TA}-2380)$ in the upper part of the Betula-Pinus PAZ indicates to the lower part of the Preboreal.

\section{The Pinus PAZ (10.32-9.24 m)}

As before Pinus is dominating. A distinct rise of the Pinus and, respectively, a decline of the Betula frequency are characteristic of the lower zone boundary. The Pinus curve reaches a maximum in the lower part of the zone and increases again near the upper limit of the zone.

Alnus has a more or less continuous curve. Ulmus and Picea are represented sporadically, Corylus is rare. The sum of herbaceous plants has decreased. 
River OPTJOK floodplain mire

$30 \mathrm{~m}$ 0.s.l.
South-Eost Estonic
pllen diagram

12
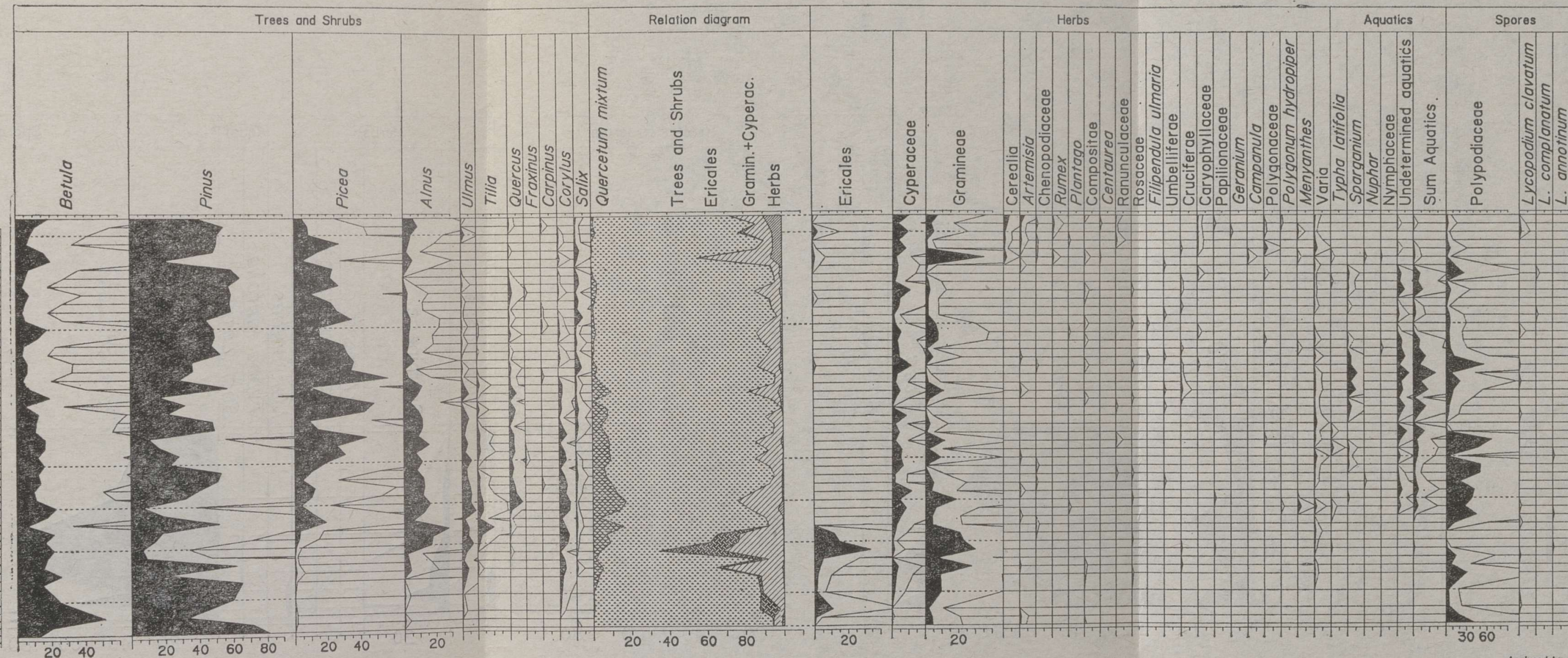
400 a 450 550 争 ว 600 啡 650 弗 $700 \mathrm{~s}$ 1000 
River OPTJOK floodplain mire detail from the lowermost

part of the pollen diagram

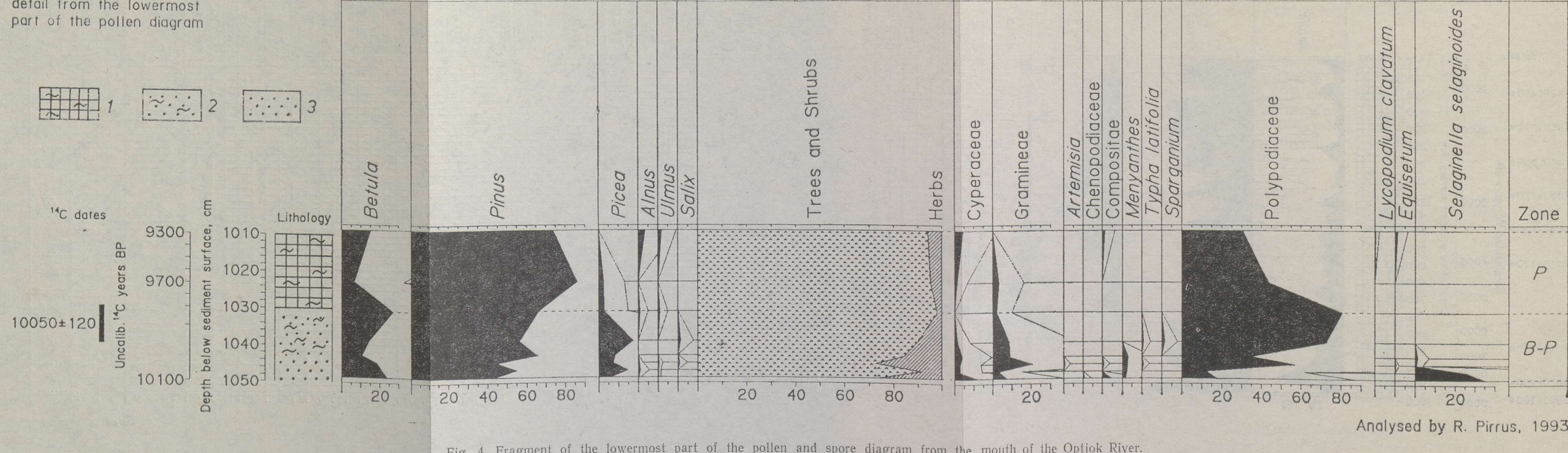

Fig. 4. Fragment of the lowermost part of the pollen and spore diagram from the mouth of the Optjok Rive 1 Phragmites peat containing a mineranogenous fraction, 2 grey silt rich in organic material, 3 grey silt. 
The content of pollen in peat is extremely low at a depth of $8.65-$ $10.0 \mathrm{~m}$ and unstable at a depth of $10.0-10.35 \mathrm{~m}$. Pollen is ill preserved. The degree of destruction, particularly of the pollen of deciduous trees, is high. It is probable that the corresponding pollen spectra are to a certain extent deformed within this interval.

The Pinus PAZ may be correlated with the Boreal chronozone.

\section{The Ulmus-Alnus PAZ (9.24-8.0 m)}

The upper boundary of the zone is fixed by a decline of the Pinus frequency, a rise of the QM, and a slight rise of the Betula curve. The constituents of QM are still represented by Ulmus. Tilia and Quercus are represented sporadically. Corylus reaches its maximum. In the lower part of the zone the empiric Picea limit is found. The Picea frequency increases towards the end of the zone. Chronostratigraphically the Ulmus-Alnus PAZ corresponds to the Early Atlantic (AT1).

\section{The Ulmus - Tilia PAZ $(8.0-7.0 \mathrm{~m})$}

The lower boundary of the zone is fixed at the rational limit of Tilia. Deciduous trees culminate in the upper part of the zone. The Quercus curve is continuous. The content of Picea pollen is slightly decreasing in the upper part of the zone.

The Ulmus-Tilia PAZ is correlated with the Late Atlantic chronozone (AT2).

\section{The Quercus-Alnus PAZ (7.0-6.0 m)}

On the lower boundary of the zone Quercus reaches its maximum. A characteristic feature is the fall of both the total and individual QM curves. Compared to the previous zone, the content of Quercus pollen is high. Alnus pollen ranges from 12 to $20 \%$, showing no decrease. The Picea pollen percentage is moderate but unstable. Carpinus and Fraxinus are scattered.

The ${ }^{14} \mathrm{C}$ date from the upper limit of the Ulmus-Alnus PAZ is $4010 \pm 110$, TA-164. Chronostratigraphically the PAZ corresponds to the Early Subboreal chronozone (SB1).

\section{The Picea PAZ $(6.0-2.8 \mathrm{~m})$}

The zone is characterized by a distinct rise of the Picea frequency. Picea is dominant, reaching its Holocene maximum. The Alnus, QM, and Betula frequencies are slightly declining. In the upper part QM and Alnus occur in very low amounts. Occasional Fraxinus pollen grains have been found. Carpinus is rare.

Two abrupt short-term decreases of the Picea pollen have been detected within the zone. The decrease in the lower part of the zone is accompanied by a considerable increase in the Pinus and Alnus pollen. In the upper part of the zone the Picea pollen decrease is accompanied by an increase in the share of Betula, Alnus, and NAP.

The ${ }^{14} \mathrm{C}$ date from the uppermost part of the zone is $2650 \pm 80$, TA-1961. The Picea PAZ would range into the Late Subboreal chronozone (SB2).

\section{The Picea-Pinus PAZ (2.8-0.6 m)}

At the lower boundary the Picea curve falls rapidly. Pinus is dominating. The amount of Betula pollen reaches $20 \%$. In the general part of the zone the Picea frequency is commonly relatively high but unstable.

Below the uppermost rise in the Picea pollen content the frequencies of Betula and Alnus are remarkable. The Picea pollen amounts only 
to $10 \%$. At the same time the rise of herbaceous plants and the appearance of Cerealia pollen are observed. Rumex, Chenopodiaceae, and Artemisia have been identified.

This PAZ is correlated with the Subatlantic chronozone (SA1 and SA2). The boundary between SA1 and SA2 at a depth of $200 \mathrm{~cm}$ has been fixed according to ${ }^{14} \mathrm{C}$ date $(1960 \pm 110$, TA-1960).

8. The Pinus-Betula-Alnus PAZ $(0.6-0.0 \mathrm{~m})$

The Picea curve is falling. Picea pollen forms only $6-10 \%$. As before Pinus is dominating. The Betula and Alnus frequencies are increasing. Cerealia has a continuous curve and it is rising. Artemisia is represented regularly; its amount ranges from 3 to $5 \%$. Chenopodiaceae, Rumex, Plantago, and Centaurea cyanus are observed.

The Pinus-Alnus PAZ is correlated with the Late Subatlantic chronozone (SA3).

Altogether ten ${ }^{14} \mathrm{C}$ dates were obtained on the organic matter (fen peat) enclosed in the deposits in the Optjok River Valley profile (Table).

${ }^{14} \mathrm{C}$ datings (age $1 / 25568 \mathrm{yr}$, uncalibrated)

\begin{tabular}{|c|c|c|c|c|}
\hline No. & Lithology of samples & Depth, m & Lab. No. & Age \\
\hline 1 & $\begin{array}{l}\text { Boundary of organic-rich } \\
\text { silt and silty peat }\end{array}$ & $10.3-10.4$ & TA-2380 & $\begin{array}{l}10050 \pm 120 \\
\text { Lower part of } \\
\text { Betula-Pinus PAZ }\end{array}$ \\
\hline 2 & Phragmites peat & $9.9-10.0$ & TA-2379 & $\begin{array}{l}8800 \pm 100 \\
\text { Lower part of } \\
\text { Pinus PAZ }\end{array}$ \\
\hline 3 & Phragmites peat & $9.4-9.5$ & TA-2378 & $\begin{array}{l}8620 \pm 100 \\
\text { Pinus PAZ }\end{array}$ \\
\hline 4 & $\begin{array}{l}\text { Phragmites peat with } \\
\text { detritus of subfossil } \\
\text { molluscs }\end{array}$ & $8.4-8.5$ & TA-2377 & $\begin{array}{l}6520 \pm 120 \\
\text { Upper part of } \\
\text { Ulmus-Alnus } \mathrm{PAZ}\end{array}$ \\
\hline 5 & $\begin{array}{l}\text { Phragmites peat containing } \\
\text { silt }\end{array}$ & $5.9-6.0$ & TA-1964 & $\begin{array}{l}4010 \pm 110 \\
\text { Upper limit of } \\
\text { Quercus-Alnus } \\
\text { PAZ }\end{array}$ \\
\hline 6 & $\begin{array}{l}\text { Phragmites peat with shell } \\
\text { fragments }\end{array}$ & $4.9-5.0$ & TA-1963 & $\begin{array}{l}3630 \pm 120 \\
\text { Lower part of } \\
\text { Picea PAZ }\end{array}$ \\
\hline 7 & $\begin{array}{l}\text { Phragmites peat with shell } \\
\text { fragments }\end{array}$ & $3.9-4.0$ & TA-1962 & $\begin{array}{l}2850 \pm 120 \\
\text { Picea } \mathrm{PAZ}\end{array}$ \\
\hline 8 & $\begin{array}{l}\text { Phragmites peat with shell } \\
\text { fragments }\end{array}$ & $2.9-3.0$ & TA-1961 & $\begin{array}{l}2650 \pm 80 \\
\text { Upper part of } \\
\text { Picea PAZ }\end{array}$ \\
\hline 9 & Phragmites peat & $1.9-2.0$ & TA-1960 & $\begin{array}{l}1960 \pm 110 \\
\text { Picea-Pinus PAZ }\end{array}$ \\
\hline 10 & Phragmites peat & $0.9-1.0$ & TA-1959 & $\begin{array}{l}1240 \pm 80 \\
\text { Upper part of } \\
\text { Picea-Pinus PAZ }\end{array}$ \\
\hline
\end{tabular}




\section{DISCUSSION}

It has been stated that after the deglaciation of the Estonian territory during the transition from the Late-Glacial to the Holocene the southern part of Lake Peipsi dried up (Орвику, 1960; Раукас \& Ряхни, 1969; Davydova \& Raukas, 1986; Miidel \& Raukas, 1991). At the same time there are data suggesting that a shallow body of water or a number of small lakes still remained there (Пиррус et al., 1985; Давыдова \& Киммел, 1991). The data obtained by the authors of the present study from the mouth of the Optjok River confirm the latter standpoint.

The results available from previous investigations furnish a basis for the conclusion that not later than at the beginning of the Preboreal a shallow body of water must have existed in the southern part of the depression of Lake Peipsi. Silts were deposited in that lake at the mouth of the present-day Optjok River. However, it should be pointed out that in the studied area also older deposits have been identified. Silts dating from the Younger Dryas with plant remains are known from the Laane section and a kilometre upstream from the mouth of the Rovja River at a depth of $4.25-5.0 \mathrm{~m}$. Due to the scanty data available it is still unclear whether these deposits give evidence of the existence of a water basin already in the Younger Dryas.

It is not clear either what the water level of the Preboreal lake was in comparison with the modern one. The water level had to be considerably lower than at present in the mouth of the Optjok River. The shallowness of the lake of that time and the paludification of its surroundings are proved by the presence of the pollen of Cyperaceae, Gramineae, Typha latifolia, Filipendula ulmaria, and the spores of Equisetum and Dryopteris thelypteris in the deposits. Pollen of the aquatics Myriophyllum verticillatum, M. spicatum, and Potamogeton sp. was also common (Пиррус \& Тасса, 1981; Пиррус et al., 1985; Давыдова \& Киммел, 1991). At the same time the lake was probably rather deep in the deepest parts of the basin. For example, two sections from the middle part of the depression of Lake Peipsi are at a distance of $200 \mathrm{~m}$ from each other. The difference in the heights of the upper boundaries of the Preboreal is $7.5 \mathrm{~m}$. However, the difference in the altitudes of the borehole mouths is only $1 \mathrm{~m}$. Therefore, the lake had to be at least $7.5 \mathrm{~m}$, maybe even $1-2 \mathrm{~m}$ deeper at that point.

Around the beginning of the Preboreal (mouth of the Optjok River) or even the Boreal chronozone (Värska Bay) the sedimentation of silty deposits was replaced by the deposition of organic-rich silt or fen peat containing silt (Figs. 3, 4). A large number of spores of the Late Glacial relict Selaginella selaginoides and to a certain extent also the content of the pollen of Chenopodiaceae and Artemisia indicate that in the Optjok section these sediments are related namely to the beginning of the Preboreal chronozone. This conclusion is also supported by the ${ }^{14} \mathrm{C}$ date of $10050 \pm 120$, TA-2380.

Probably the abrupt change in the sedimentation was caused by the lowering of the lake level. At the time the formation of fen peat commenced at the mouth of the Optjok River the water level had to be at least $10 \mathrm{~m}$ lower than at present. The southern part of the lake basin was occupied by a swamp, where Phragmites, Typha latifolia, Menyanthes, Equisetum, Cyperaceae, Salix, and Dryopteris thelypteris dominated.

From the beginning of the Preboreal chronozone until the beginning of the Boreal chronozone conditions for the sedimentation of peat were extremely unfavourable. Therefore, there could even be a hiatus in the second half of the Preboreal. The break in the sedimentation probably 
marks the lowest water level in the Holocene approximately 10 000-9000 years BP. According to Davydova and Kimmel (Давыдова \& Киммел, 1991) the hiatus is also traceable in the deepest part of the depression

The rise of the water level in the lake, following its low level during the Preboreal, started from the south. According to the investigated Optjok site the water level started to rise slowly already in the first half of the Boreal. The process was accompanied by the growth of reed peat containing woody remains. Somewhat to the north, in Värska Bay, a slow rise is observed in the second half of the Boreal. At the same time the content of gyttja and silty material was increasing in the reed peat. Pollen of Nuphar luteum was also found (Пиррус \& Tacca, 1981).

In the Atlantic chronozone the accumulation of reed peat with shell fragments continued indicating the water-level rise in the mouth of the Optjok River (Figs. 3, 5). Since the second half of this chronozone pollen grains of water plants are permanently present in the deposits. At the same time an intense deposition of gyttja began in Värska Bay (Пиррус \& Tасса, 1981).

In the Subboreal chronozone no marked changes in the lithology of the deposits occurred. However, some features referring to a significant change in the hydrological regime of the lake can still be found. The reed peat at the mouth of the Optjok River contains an abundance of water plant pollen. Among others Sparganium pollen is found in particularly large amounts. This information and the fast increase in the growth of fen peat at the beginning and especially in the second half of the Subboreal chronozone suggest a rapid rise of the water level (Fig. 5).

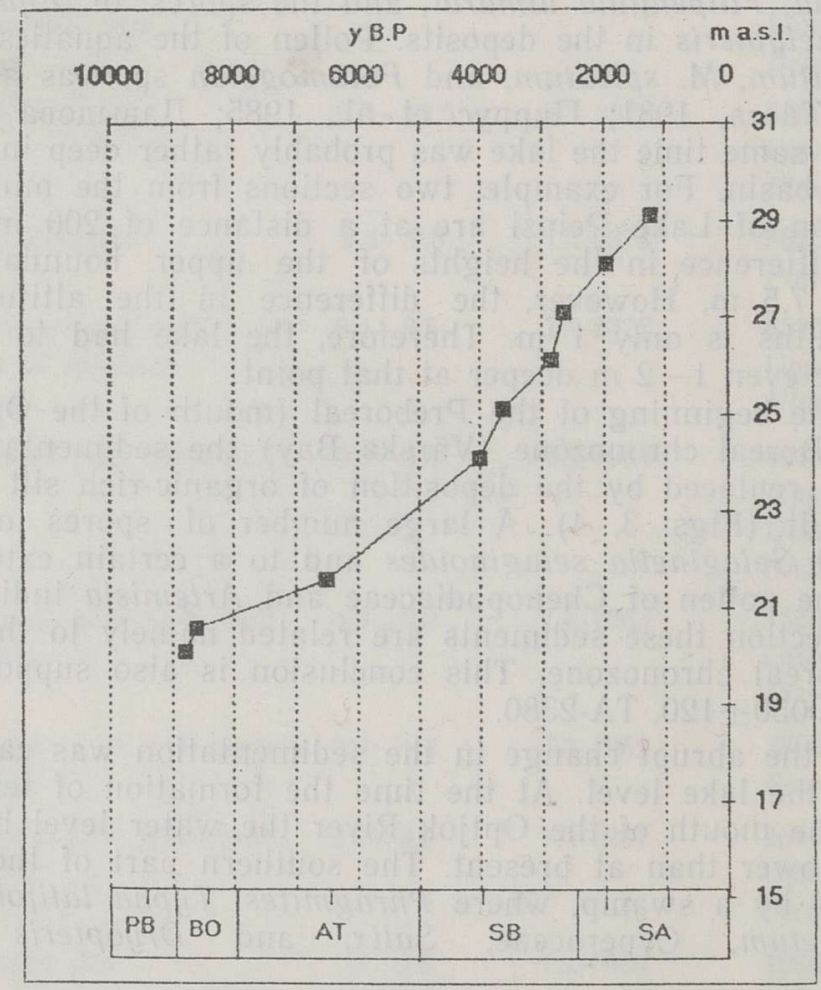

Fig. 5. Curve of the water-level changes at the mouth of the Optjok River in the Holocene drawn assuming that the water-level rise and the growth of fen peat were balanced, 
The water-level rise also continues at the beginning of the Subatlantic chronozone. It is relatively swift, but considerably slower than earlier. In many cases the alga Pediastrum has been found in peat deposits, in particularly great amounts in the second half of the chronozone. These data indicate frequent and long-term floodings at the lower reaches of rivers. In comparison with the Early and Middle Holocene the water level rose considerably faster in the Late Holocene. As a result, the southern bank of the lake was subject to extensive paludification that spread to the lower reaches of the rivers as well.

Some conclusions drawn on the basis of the rate of peat formation about the water-level changes in Lake Peipsi during the Holocene might be of interest. It could be presumed that the water-level rise in Lake Peipsi and the growth of fen peat in the lower reaches of rivers were more or less balanced. In that case Fig. 5 will approximately simulate the water-level rise in the studied area. Considering the inaccuracy of this approach and few ${ }^{14} \mathrm{C}$ datings, unevenly distributed in the profiles, it is difficult to conclude whether the water-level rise in the Holocene took place evenly (Мийдел, 1981) or with notable fluctuations. Still, it can be stated that the water-level rise fastened in the second half of the Subboreal chronozone (Fig. 5). Then it is almost possible to speak of a transgression. However, its reasons are not clear yet. The water-level rise in the southern part of the depression is considered to have been caused by an intense glacioisostatic uplift, greater in the north (Hausen, 1913; Ramsay, 1929; a.o.). However, this alone cannot bear the whole responsibility for the rapid water-level rise in the Subboreal chronozone when the rate of the uplift in Estonia, on the contrary, decreased (Кессел \& Мийдел, 1973). This could advance other factors, for instance climatic, to come out from the shadow of the land uplift. Although the comparison of the development of large and small lakes is quite questionable, the supposition is supported somewhat by the data on the investigations of small lakes. According to Saarse and Harrison (1992) the water level in the small lakes of Estonia has risen during the last 5000 years, though there was a dry period 4000 years ago. Davydova and Raukas (1986) have established that at the end of Subboreal time, about 3000 years BP, the water level began to rise in the small lakes of the NW part of the Russian Plain. In the southern part of Lake Võrtsjärv the fast sedimentation rate of gyttja since the second half of the Subboreal chronozone (Пиррус et al., 1993) also points to the significant role of climate. Besides, it is supposed that the southern part of Lake Peipsi is a young subsiding local structure (Мийдел, 1966), but there is no data available to confirm the Subboreal age of the structure. In view of this it would be untimely to give a firm reply to the above question. The reason for rapid water-level rise seems to be hidden in the combined effect of climate and tectonic movements.

The short-term decreases of Picea pollen in the SB2 chronozone (Picea PAZ) are probably indicators of the human impact. At first it could have been connected with the local burning of forest. It was followed by an increase in the representatives of Caryophyllaceae, Compositae, Cruciferae, and Umbelliferae and with an increase in herbaceous pollen. Clear signs of agricultural activities are observed from the midst of SA2 chronozone (c. 1500 years BP). A continuous Cerealia curve appears. The weeds Chenopodiaceae, Artemisia, Rumex, and Centaurea cyanus and meadow plants (Caryophyllaceae, Plantago, Ranunculaceae, Campanula, Geranium) are common. Also the content of herbaceous pollen increases remarkably. 


\section{CONCLUSIONS}

The investigated site at the mouth of the Optjok River confirms the existence of a shallow body of water in the southern part of the Lake Peipsi depression at the beginning of the Preboreal. The water level in the lake was considerably lower than at present. According to the available data the water depth in the deepest part of the depression was about $7.5 \mathrm{~m}$. The rapid change in sedimentation at the end of the Preboreal was due to the lowering of the water level. Accordingly, the southern part of the depression turned to a fen. The accumulation of fen peat indicates a water-level rise from the beginning of the Boreal. The tendency to water-level rise continues during the whole Atlantic. A relatively fast water-level rise is observed since the second half of the Subboreal time, which could be considered as a transgression. The latter is also characterized by the short-term water-level rises about 4000 and 3000 years BP. The combination of climate and tectonic movements is considered to be the main reason responsible for the waterlevel rise. The idea about the effect of climate is also supported by the water-level data from small lakes (Davydova \& Raukas, 1986; Saarse \& Harrison, 1990) and by the sedimentation rate of gyttja. Another source of the water-level rise in the southern part of Lake Peipsi is the glacioisostatic uplift. It is faster in the northern part of the depression and decreases southwards, where now a tendency to subsidence appears. Nevertheless, the uneven water-level rise can hardly be explained only with neotectonic movements.

The data presented above throw new light upon the low water level at the end of the Late Glacial or at the beginning of the Holocene. As is known, the deep downcutting of rivers and the direction of their valleys at the bottom of Lake Peipsi in its middle and southern parts have been connected namely with this low stand in the water level (Opвику, 1960; Hang et al., 1964; Мийдел, 1966; Раукас \& Ряхни, 1969; Miidel \& Raukas, 1991). On the ground of the section studied, the abovementioned events must have taken place considerably earlier. Though the water level at the beginning of the Holocene was markedly lower, it could not have dropped so much as to bring about the formation of deep river valleys. And this mainly for two reasons. Firstly, Lake Peipsi had become isolated from the Baltic Sea by that time. Considering the altitudes of possible thresholds, the water level as the base level for rivers could not drop c. $10 \mathrm{~m}$ below the present lake level. And secondly, the tilting of the lake basin from the north to the south, caused by glacioisostatic movements, had started. This process laid down a new tectonic background, contrary to the hitherto existing. However, an analysis of this situation is beyond the present study and is worth separate discussion.

\section{ACKNOWLEDGEMENTS}

This study was supported by grant No. 324 of the Estonian Science Foundation and the Institute of Geology, Estonian Academy of Sciences. The comments of Anto Raukas and Leili Saarse, who critically read the manuscript, have been most valuable. Helle Kukk corrected and improved the language. The computer layout of the pollen diagrams was made by Siim Veski. The drawings were made by Paul Pärkma. Aivo Lepland and Aulis Saarniits helped with field work. To all these people we are very grateful. 


\section{REFERENCES}

Davydova, N. \& Raukas, A. 1986. Geological development of large lakes of the humid zone in the European part of the Soviet Union, and Holocene climatic changes on the basis of lake sediment data. - J. Biogeogr., 13, 173-180.

Hang, E., Liblik, T. \& Linkrus, E. 1964. On the relations between Estonian valley terraces and lake and sea levels in the Late-Glacial and Holocene periods. Transactions of Tartu State University, 156. Publications on geography, IV, $29-42$

Hausen, H. 1913. Uber die Entwicklung der Oberflächenformen in den russischen Ostseeländern. - Fennia, 34, 2.

Mangerud, J., Andersen, S. T., Berglund, B. E. \& Donner, J. J. 1974. Quaternary stratigraphy of Norden, a proposal for terminology and classification. Boreas 3, 109-128.

Miidel, A. \& Raukas, A. 1991. The evolution of the river systems in the east Baltic. In: Starkel, L., Gregory, J. K. \& Thornes, J. B. (eds.). Temperate Palaeohydrology, J. Wiley, Chichester, 365-380.

Ramsay, W. 1929. Niveauverschiebungen, eisgestaute Seen und Rezession des Inlandeises in Estland. - Fennia, 52, 2.

Saarse, L. \& Harrison, S. P. 1992. Holocene lake-level changes in the eastern Baltic region. - In: Estonia. Man and Nature. Estonian Geographical Society, Tallinn, 6-20.

Давыдова Н., Киммел К. 1991. К палеогеографии Псковско-Чудского озера по материалам биостратиграфического изучения донных отложений. - Изв. АН Эстонии. Геол., 40, 1, 16-23.

Кессел Х., Мийдел А. 1973. О поздне- и послеледниковых движениях земной коры на территории Эстонии. - Изв. АН ЭССР. Хим. Геол., 22, 3, 257-264.

Мийдел А. 1966. О связи между современными движениями земной коры и эрозионно-аккумулятивной деятельностью рек Эстонии. - Изв. АН ЭССР. Сер. физ.-матем. и техн. наук, XV, $1,121-133$.

Мийдел А. 1981. О проблемах изучения неотектонических движений в ПсковскоЧудской впадине. - In: Раукас А. В. (ed.). Донные отложения ПсковскоЧудского озера. Таллинн, 116-126.

Орвику К. К. 1960. О неотектонических движениях в Э๔тонской ССР на основе геологических данных. - In: Материалы совещания по вопросам неотектонических движений в Прибалтике. Тарту, 120-143.

Пиррус Р. О., Мийдел А. М., Раукас А. В. 1985. К голоценовому развитию ПсковскоЧудского озера. - In: Алекин О. А., Смирнова Н. П., Сорокин И. Н. (eds.). Проблемы исследования крупных озер СССР. Наука, Ленинград, 163-167.

Пиррус Р., Тасса В. 1981. Геология месторождения сапропеля в заливе Вярска. In: Раукас А. В. (ed.). Донные отложения Псковско-Чудского озера. Таллинн, 82-93.

Пиррус Р., Ханг Т., Лийва А. 1993. О геологическом развитии долины реки ВяйкеЭмайыги и южной части озера Выртсъярв. - Изв. АН Эстонии. Геол., 42, $1,28-37$.

Раукас А., Ряхни Э. 1969. О геологическом развитии впадины и бассейнов Чудского и Псковского озер. - Изв. АН ЭССР. Хим. Геол., 18, 2, 113-127.

\section{PEIPSI JÄRVE LOUUNAOSA ARENGUST HOLOTSEENIS}

Avo MIIDEL, Tiit HANG, Reet PIRRUS, Arvi LIIVA

Optjoki jõe suudmes paikneva puuraugu palünoloogilise uurimise tulemused ja geoloogilised andmed tõendavad, et Preboreaali alguses oli Peipsi järve lõunaosas madalaveeline veekogu. Preboreaali lôpuks tekkis veetaseme edasise langemise tõttu järvenõo lõunaosas madalsoo. 
Järve veetase oli kuni $10 \mathrm{~m}$ praegusest madalam. Aeglane veetaseme tõus algas Boreaali esimesel poolel, jätkus ühtlaselt Atlantikumis Subboreaali teise pooleni ning kiirenes seejärel. Veetase tõuseb praegugi ja selle tagajärjel on järvenõoga piirnevad alad soostunud. Soostumine levis ka jõgede alamjooksule. Oletatavasti on veetaseme tõusu põhjused nii klimaatilised kui ka tektoonilised. Peipsi Iõunaosas pidi jõgede sügav sisselõikumine allapoole järve praegust veepinda toimuma seniarvatust varem.

\title{
О РАЗВИТИИ ЮЖНОЙ ЧАСТИ ЧУДСКОГО ОЗЕРА В ГОЛОЦЕНЕ
}

\author{
Аво МИЙДЕЛ, Тийт ХАНГ, Рээт ПИРРУС, Арви ЛИЙВА
}

Палинологическое исследование разреза, вскрытого скважиной в устье р. Обдех, и геологические данные доказывают, что в начале пребореала южная часть Чудской впадины была мелководной и к концу пребореала, в связи с дальнейшим обмелением, местами превратилась в низинное болото. Уровень озера был на 10 м ниже современного. Медленное поднятие воды началось в первой половине бореала, прежде всего на южных участках и в понижениях рельефа, и продолжалось в течение атлантического периода до второй половины суббореала. Затем повышение уровня воды в озере ускорилось. Этот процесс наблюдается и в настоящее время, в результате чего происходит заболачивание не только прилегающих к озеру территорий, но и низовий рек. Предполагается, что повышение уровня воды обусловленіо как климатическими, так и тектоническими причинами. Высказывается мнение, что глубокое врезание рек ниже современного уровня озера должно было произойти значительно раньше, чем считалось до сих пор. 